\title{
Knowledge regarding mosquito borne diseases \& control measures practiced among a rural population in a southern district of Tamil Nadu, South India
}

\author{
Ben Nelson S. ${ }^{1 *}$, G Ashok V. ${ }^{2}$, Nazer M. ${ }^{3}$, Manibalan S. ${ }^{4}$ \\ DOI: https://doi.org/10.17511/ijphr.2017.i1.02 \\ 1* Sudhir Ben Nelson, Assistant Professor, Department of Community Medicine, Sree Mookambika Institute of Medical Sciences, \\ Kulasekharam, Tamil Nadu, India. \\ 2 Vishnu G Ashok, Assistant Professor, Department of Community Medicine, Sree Mookambika Institute of Medical Sciences, Kulasekharam, \\ Tamil Nadu, India. \\ 3 Madiha Nazer, CRRI, Department of Community Medicine, Sree Mookambika Institute of Medical Sciences, Kulasekharam, Tamil Nadu, \\ India. \\ 4 Manibalan S, CRRI, Department of Community Medicine, Sree Mookambika Institute of Medical Sciences, Kulasekharam, Tamil Nadu, \\ India.
}

Introduction: Vector-borne diseases account for over $17 \%$ of all infectious diseases. Up to 700 million people are infected and more than a million die each year from mosquito-borne illness. The extent of people's cooperation can determine the success or failure of the entire campaign for Mosquito control. Methods: A cross-sectional observational study was carried out in Kanyakumari district among 180 individuals selected through multi-stage sampling. Data was collected using a semi structured interview schedule. Results: Every one of the study participants knew that mosquitoes spread diseases. Dengue was the most common disease related to Mosquito. Among the respondents, $113(62.7 \%)$ answered that coconut shells most common mosquito breeding place. Coconut shells (66\%) \& Open drainages (61.1\%) were reason for water stagnation inside \& outside their own compound respectively. $71.1 \%$ have seen mosquito larva in stagnant water around their house and among them $75.8 \%$ have done something to kill larva. Conclusion: A good proportion of the households are taking preventive measures, but still so many households lacks practice or found to be doing wrong practices. Therefore, we recommend that community should be empowered with the right $\&$ adequate knowledge.

Keywords: Mosquito Borne diseases, Coconut shells, Bleaching powder, Mosquito coils

Corresponding Author

Sudhir Ben Nelson, Assistant Professor, Department of Community Medicine, Sree Mookambika Institute of Medical Sciences, Kulasekharam, Tamil Nadu, India.

Email: sudhirben@gmail.com
How to Cite this Article

To Browse

Nelson SB, Ashok VG, Nazer M, Manibalan S. Knowledge regarding mosquito borne diseases \& control measures practiced among a rural population in a southern district of Tamil Nadu, South India. Public Health Rev Int J Public Health Res. 2017;4(1):9-12.

Available From

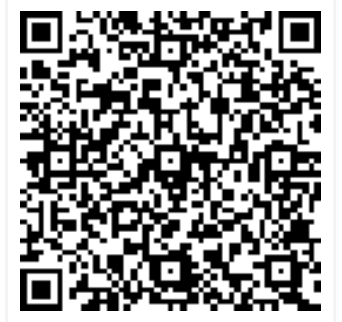

https://publichealth.medresearch.in/index.php/ijphr/ article/view/55

\begin{tabular}{|c|c|}
\hline $\begin{array}{c}\text { Manuscript Received } \\
2017-01-25\end{array}$ & $\begin{array}{c}\text { Review Round } 1 \\
2017-02-02\end{array}$ \\
\hline $\begin{array}{c}\text { Conflict of Interest } \\
\text { No }\end{array}$ & $\underset{\mathrm{Nil}}{\text { Funding }}$ \\
\hline
\end{tabular}

$$
\begin{aligned}
& \text { Review Round } 2 \\
& \text { 2017-02-11 } \\
& \text { Ethical Approval } \\
& \text { Yes }
\end{aligned}
$$




\section{Introduction}

Vector borne diseases (VBD) are infectious diseases transmitted through insects such as mosquito, house fly, sand fly, lice, ticks, flea etc. Vectors can be classified as mechanical or biological vectors. Mechanical vectors like housefly pickup infectious agents on the surface of their bodies and transmit them through physical contact. Biological vectors like mosquitoes carry the pathogens within their bodies and transmit them to a new host while biting [1].

Vector borne diseases are prevalent all over the world, especially in tropical regions. With the introduction of insecticides, the VBDs were thought to be under control by the late 1960s. But following compliancy in continuing control measures \& changing environment Vector borne diseases (VBD) again became a major Public Health problem. The World Health Organization (WHO) brought VBDs into focus during the World Health day of 2014 [2].

Vector-borne diseases account for over $17 \%$ of all infectious diseases [3]. Among all diseasetransmitting insects, the mosquito is the greatest menace, spreading malaria, dengue, yellow fever, lymphatic Filariasis and Japanese encephalitis among others. Up to 700 million people are infected and more than a million die each year from mosquito-borne illness [4]. Among these Malaria, Dengue, Lymphatic Filariasis, Kala-azar, Japanese Encephalitis and Chikungunya are prevalent in India.

About $95 \%$ population in the country resides in malaria endemic areas and $80 \%$ of malaria reported in the country is confined to areas consisting $20 \%$ of population residing in tribal, hilly, difficult and inaccessible areas [5]. The Mosquito borne diseases pose an immense public health concern and are major impediments in the path of socioeconomic development. The National Vector Borne Diseases Control Program (NVBDCP) was started to provide an integrated approach to the control of VBD particularly Mosquito borne diseases in the country.

Indicators have been developed at national level for monitoring of the program. The main strategy is integrated vector management which involves source reduction \& environmental management, Personal protection, chemical and Biological control [6]. The mosquito breeding places include coconut shells, drainage, plantations, open wells, containers, vehicle tyres.
It is expected that anti-larval measures along with personal protection measures if done properly could bring the Mosquito borne diseases under control. To achieve best results in vector control it is imperative to have active community participation. Most organized vector control strategies require public support of one kind or another and the extent of people's cooperation can determine the success or failure of the entire campaign.

There is limited information on the Knowledge, Attitude \& Practice (KAP) components of the community in relation to the mosquitoes and their control in India. Therefore, we thought it would be a worthwhile endeavor to conduct a cross-sectional study in selected areas of Kanyakumari district to find out the knowledge regarding mosquito borne diseases, current mosquito control practices among rural population.

\section{Aim \& Objective}

To assess the knowledge and practice about mosquito borne diseases and its control measures among general population.

\section{Methods}

Type of study: Cross-sectional observational study.

Place of study: Two panchayats of Kanyakumari district. Study Period: August to September 2015.

Sample size: The sample size was calculated by formula $\mathrm{N}=[4 \mathrm{pq} / \mathrm{d} 2]$ (where $\mathrm{d}$ is allowable error (taken as $20 \%$ of p), $p$ taken as $72 \%$ ). $20 \%$ was added to account for non-respondents thus giving a sample size of 186 .

Inclusion criteria: Individual of both sexes above 18 yrs of age who have been living in the same house for more than 6 months.

Exclusion criteria: Those who did not wish to participate or claimed not to possess proper information were excluded.

Sampling methods: The sample of 186 was divided into 2 (93 from each panchayat). 9 streets from each panchayat were selected by simple random method. From 6 of the 9 streets, 10 households each were selected starting from the first house. For the rest of the 3 streets 11 households each were selected. Only those households that had existed in that area for more than 6 months were included. 
From each household one person who fulfilled the inclusion criteria was selected. Out of 186, 6 did not wish to participate or could not provide proper information. Thus 180 people took part in the study finally.

Data collection: The data was collected by a face to face interview using a semi structured interview schedule on knowledge about Mosquito borne diseases and the practice of Mosquito control measures. Data was entered in Microsoft excel Office 2007.

Statistical methods: Data was analyzed using PSPP version.0.10.2 and Frequencies were expressed.in percentages.

\section{Results}

In this study, the most common age group was 4160 , which constituted $44.4 \%$ and $70 \%$ of the study participants, were female. Among all study participants $7(3.9 \%)$ had not received any schooling. Every one of the study participants knew that mosquitoes spread diseases. Dengue was the most frequent disease related with mosquito by the respondents i.e. by $146(81.1 \%)$.

However, none of them thought of Filariasis (Table $-1) .93 .9 \%$ of them were aware of breeding places of mosquito. Among the respondents, $113(62.7 \%)$ answered that coconut shells was the most common mosquito breeding place. $70.6 \%$ people said that there was no stagnation inside their compound wall. Among the rest, $66 \%$ said that coconut shells were reason for water stagnation inside their own compound wall.

$61.1 \%$ people said that drainage was the reason for water stagnation outside their compound wall. Among the study participants, $128(71.1 \%)$ have seen mosquito larva in stagnant water around their house and among them $97(75.8 \%)$ persons have done something to kill larva. Most common method used against Mosquito Larva by these people was putting bleaching powder in the larva breeding places $(39 \%)$ followed by source reduction $(26.5 \%)$.

Among the respondents $44.4 \%$ strongly felt that children are more susceptible to mosquito borne diseases. More than half $(56.1 \%)$ of people said that prevention of stagnation is an important method to prevent these diseases. $71.1 \%$ people had done something to prevent mosquito breeding and they used bleaching powder $(57 \%)$ as the main method(Table-2).
$78.9 \%$ of the households were using personal protective measures to prevent mosquito bites. Majority among them i.e. 85 people $(59.8 \%)$ were using mosquito coil (Table-3). $75 \%$ people said that government have taken measure to control mosquito and most common used measure was fogging. Among this $75 \%, 52(38.5 \%)$ said fogging was done in their area in past 6 months, $17(12.5 \%)$ of them said only inspection was done and the rest did not know the measures taken by the government.

Table- 1: Knowledge: Disease related to Mosquito

\begin{tabular}{|l|l|l|}
\hline \multicolumn{1}{|c|}{ Disease } & \multicolumn{1}{c|}{ Number } & \multicolumn{1}{c|}{ Percentage } \\
\hline Dengue & 146 & $81.1 \%$ \\
\hline Malaria & 111 & $61.6 \%$ \\
\hline Chikungunya & 36 & $20 \%$ \\
\hline Filariasis & 0 & $0 \%$ \\
\hline
\end{tabular}

Table- 2: Most commonly used method to control Mosquitoes $(\mathbf{N}=\mathbf{1 2 8})$

\begin{tabular}{|l|l|l|}
\hline \multicolumn{1}{|c|}{ Methods } & No of Households & Percentage \\
\hline Bleaching Powder & 73 & $57 \%$ \\
\hline Preventing Unnecessary water collection & 35 & $27.3 \%$ \\
\hline Maintaining Clean Environment & 8 & $6.3 \%$ \\
\hline pouring oil & 7 & $5.5 \%$ \\
\hline Fishes & 5 & $3.9 \%$ \\
\hline
\end{tabular}

Table- 3: Personal Protective Measures used ( $N=142 \#)$

\begin{tabular}{|l|l|l|}
\hline \multicolumn{1}{|c|}{ Measures } & No of Households & Percentage \\
\hline Mosquito Repellent coils & 85 & $59.8 \%$ \\
\hline Mosquito Repellent Mats & 40 & $28.1 \%$ \\
\hline Bed nets & 21 & $14.7 \%$ \\
\hline Window screen & 10 & $7 \%$ \\
\hline Burning various material\$ & 8 & $5.6 \%$ \\
\hline Mosquito Repellent Liquids & 5 & $3.5 \%$ \\
\hline \# Some Households use more than one measure. \\
\$ Sambrani, Neem leaves, Agarbattis \& other natural products
\end{tabular}

\section{Discussion}

The mosquito borne disease known to most of the people in our study was dengue $(81 \%)$ but in the study conducted in Jamnagar district in Gujarat [7] it was malaria $(90.6 \%)$. This is because malaria is more prevalent in Gujarat and dengue is more prevalent Kanyakumari district. The district was once endemic for Filariasis. However, none of the participants thought about it. This may be due the success of the Filarial control program, which has pushed the disease out of the community \& from its collective mind. 
In a study in Jamnagar district [7] $38 \%$ of the houses had open para-domestic drainage system that is conducive for mosquito breeding, while $66.6 \%$ households had open drainage for mosquito breeding in our study. Open drainage is a common breeding area in Kanyakumari district because of poor public health engineering and improper maintenance.

$62 \%$ people told coconut shells as the most common breeding area for mosquito in our study but only $2.31 \%$ said coconut shells in a study conducted in Rajkot district, Gujarat [8]. In Gujarat ditches and vehicle tyres are the most common mosquito breeding places. This difference might be due abundance of coconut trees in our study locality.

$71.1 \%$ in our study have seen larva and among them $39 \%$ were using bleaching powder as the antilarvicidal method, which is not the advised method. This shows that although the public knew the importance of Controlling the mosquito \& are willing to get involved personally there is lake of guidance towards the proper preventive methods. 56.1\% people said that prevention of stagnation is the main method to prevent mosquito borne diseases, but in a study conducted in Rajkot district of Gujarat [8] only $17.59 \%$ respondents had a similar opinion.

For them larvicidal spraying, and personal protective measures was their common idea for preventing mosquito borne disease. . In our study, $71.1 \%$ have taken initiative to prevent mosquito breeding. However, 57\% people were using bleaching powder to reduce mosquito breeding which is not an ideal method. Only $35 \%$ of the households stated that they have taken measures to prevent mosquito breeding in a study within the same state conducted in Chennai [9].

This may be suggestive of better community responsibility \& participation in rural areas. Also in rural areas of Kanyakumari district, in most households the family owns at least a small area around the house, and hence they will have the authority \& responsibility to prevent mosquito breeding.

$30 \%, 13.43 \%, 50.4 \%$ have mentioned the use of mosquito coils in studies conducted in Jamnagar district, Rajkot district and Tibet respectively $[7,8,10]$ and in our study $47 \%$ use mosquito coils. $2.7 \%$ people uses bed nets in a study conducted in Thiruvananthapuram [11] and in our study $11 \%$ people uses bed nets.
This may be due to deference in the socioeconomic composition between our area and Thiruvananthapuram.

\section{Conclusion}

Knowledge about the importance of mosquito control is universal but specific knowledge regarding control measures was not that satisfactory. A good proportion of the households were using preventive measures against mosquito breeding places and mosquito bites, but still so many households lacks practice and also found to be doing wrong practices. So it is recommended that community should be empowered with the right $\&$ adequate knowledge to take necessary actions at household level to prevent mosquito borne diseases and the various stakeholders including public health personals \& local physicians should be encouraged to give health education to the patient about the appropriate and affordable preventive measures.

\section{Reference}

01. Vector-borne-diseases. Available from: [Article] [Crossref]

02. World Health Organization. A global brief on vector-borne diseases. Geneva- World Health Organization. 2014;54.

[Crossref]

03. World Health Organization. Vector-borne diseases. 2016 Feb.

Available from: [Article] [Crossref]

04. Caraballo H, King K. Emergency department management of mosquito-borne illnessmalaria, dengue, and West Nile virus. Emerg Med Pract. 2014 May;16(5)1-23; quiz 23-4. [Crossref]

05. Gupta I, Chowdhury S. Economic burden of malaria in India- The need for effective spending. WHO South-East Asia Journal of Public Health. 2014 Jan-Mar;3(1)95-102.

DOI: $\quad 10.4103 / 2224-3151.115828 \quad$ [Crossref]

06. Directorate of National Vector Borne Diseases Control Program (NVBDCP). Operational Manual for Integrated Vector Management in India. Operational Manual. Delhi- Ministry of Health \& Family Welfare, Directorate General of Health Services. 2016;98

[Crossref] 
07. Dhaduk KM, Gandha KM, Vadera BN, Mehta JP, Parmar V, Yadav SB. A Community level KAP study on mosquito control in Jamnagar district. National Journal of Community Medicine. 2013 Apr-Jun;4(2)321-328.

[Crossref]

08. Vala M, Patel U, Joshi N, Zalavadiya D, Bhola C, Viramgami A. Knowledge and Practices regarding commonly occurring mosquito borne diseases among people of urban and rural areas of Rajkot District, Gujarat. Journal of Research in Medical and Dental Science. 2013;OctDec; 1(2)46-51.

[Crossref]

09. Ashok Kumar V, Rajendran R, Manavalan R, Tewari SC, Arunachalam N, Ayanar K, Krishnamoorthi R, Tyagi BK. Studies on community knowledge and behavior following a dengue epidemic in Chennai city, Tamil Nadu, India. Trop Biomed. 2010 Aug;27(2)330-6.

[Crossref]
10. Liu X, Wan F, Cirendunzhu, Cirenwangla, Bai L, Pengcuociren, et al. Community knowledge and experience of mosquitoes and personal prevention and control practices in Lhasa, Tibet. Int J Environ Res Public Health. 2014;Sep23;11(9)9919-37.

[Crossref]

11. Devi SR, Dass S. Environmental factors of malaria persistence- a study at Valiyathura, Thiruvananthapuram city. ThiruvananthapuramKerala Research Programme on Local Level Development, Centre for Development Studies. $1999 ; 26$.

[Crossref] 